\title{
Zapošljavanje u javnoj upravi u Hrvatskoj i Slavoniji (1868. - 1918.) s obzirom na državljanstvo i brvatsko - slavonsku pripadnost
}

\section{Ivan Kosnica*}

$\begin{array}{ll}\text { UDK } & 35.08:: 35.07(497.5)^{\prime \prime} 1868 / 1918^{\prime \prime} \\ & 35.08: 342.71(497.5)^{\prime \prime} 1868 / 1918^{\prime \prime} \\ & 10.31297 / \text { hkju.18.4.5 } \\ \text { DOI } & \text { 6. 3. } 2018 . \\ \text { Original scientific paper / izvorni znanstveni rad } \\ \text { Received / primljeno: } & 25.5 .2018 .\end{array}$

Predmet rada je zapošljavanje u javnoj upravi u Hrvatskoj i Slavoniji s obzirom na kriterije ugarsko-hrvatskog državljanstva i hrvatsko-slavonske pripadnosti u nagodbenom razdoblju. Problematizira se teza hrvatskih javnopravnih teoretičara na prijelazu iz 19. u 20. stoljeće o tome da je hrvatsko-slavonska pripadnost bila temeljni kriterij za zapošljavanje u javnoj upravi. $U$ radu se dokazuje da u nizu upravnih područja hrvatsko-slavonska pripadnost nije uspostavljena kao temeljni kriterij za zapošljavanje, nego su temeljni kriteriji bili ugarsko-hrvatsko državljanstvo te znanje hrvatskog jezika. Stoga je osnovni zaključak rada da je poznavanje hrvatskog jezika, a ne hrvatsko-slavonska pripadnost, bila brana većem zapošljavanju mađarskih činovnika i službenika u

Ivan Kosnica, Assistant professor at the Chair of Croatian Histroy of Law and State, Faculty of Law, University of Zagreb, Croatia (docent na Katedri za povijest hrvatskog prava i države Pravnog fakulteta Sveučilišta u Zagrebu, Hrvatska, e-mail: ivan.kosnica@pravo.hr)

ORCID ID: orcid.org/0000-0002-0467-6062 
Hrvatskoj i Slavoniji. Iznimka od toga bilo je zapošljavanje na državnim željeznicama na kojima je upotreba mađarskog jezika bila izražena te je to bilo razlog zapošljavanja većeg broja ugarskih pripadnika u Hrvatskoj i Slavoniji.

Ključne riječi: javna uprava, Hrvatska i Slavonija, zapošljavanje, državljanstvo, hrvatsko-slavonska pripadnost, hrvatski jezik

\section{Uvod ${ }^{* *}$}

Predmet istraživanja su hrvatsko-slavonska pripadnost i ugarsko-hrvatsko državljanstvo kao pretpostavke za zapošljavanje u javnoj upravi u Hrvatskoj i Slavoniji u nagodbenom razdoblju. Oba instituta bila su vrlo značajna u hrvatsko-slavonskom pravnom poretku. Institut ugarsko-hrvatskog državljanstva bio je temeljna pretpostavka za uživanje prvenstveno gradanskih prava u Hrvatskoj i Slavoniji (Kosnica, 2017, str. 732). Institut hrvatsko-slavonske pripadnosti bio je vrlo značajan u poslovima hrvatskoslavonske autonomije, i to kao temeljna pretpostavka biračkog prava na izborima za Hrvatsko-slavonski sabor te važna pretpostavka za uživanje pojedinih socijalnih prava (Kosnica, 2014, str. 480-485; Čepulo, 1999, str. 804). Navedena pripadnost bila je također vrlo značajna za javnopravni status Roma (Kosnica, 2017, str. 733-734, 736-738).

Iako je značaj i doseg hrvatsko-slavonske pripadnosti i ugarsko-hrvatskog državljanstva u nagodbenom razdoblju u Hrvatskoj i Slavoniji u velikoj mjeri razjašnjen u pravno-povijesnoj znanosti, ostaje još uvijek u određenoj mjeri nerazjašnjena uloga i mjesto tih instituta s obzirom na zapošljavanje u javnoj upravi u Hrvatskoj i Slavoniji u nagodbenom razdoblju. Cjelovitih modernih pravno-povijesnih analiza navedene problematike nema, a studije s kraja 19. i početka 20. stoljeća koje su pisali tada najznačajniji hrvatski javnopravni teoretičari Josip Pliverić, Vinko Krišković i Ladislav Polić, a koje se djelomično bave i problemom zapošljavanja u javnoj upravi, odveć su opterećene vremenom nastanka te namjerom autora da dokažu tezu o pravu hrvatsko-slavonskih pripadnika na službe u javnoj upravi u Hrvatskoj i Slavoniji. Detaljan pregled važećeg zakonodavstva kao

** Rad je nastao kao rezultat istraživanja na znanstvenoistraživačkom projektu Pravnog fakulteta Sveučilišta u Zagrebu. 
i pregled natječaja za radna mjesta upozoravaju na problematičnost teze o hrvatsko-slavonskoj pripadnosti kao temeljnoj pretpostavci za namještenje u javnoj upravi. Naš rad stoga ima cilj dati nov pogled na problematiku zapošljavanja u javnoj upravi u Hrvatskoj i Slavoniji u nagodbenom razdoblju te ispitati pravni okvir kao i činjenično stanje na temelju kojeg bi bio vidljiv stvaran značaj hrvatsko-slavonske pripadnosti i ugarsko-hrvatskog državljanstva kao kriterija za zapošljavanje u javnoj upravi.

U radu se uvodno izlaže tradicija zapošljavanja u Hrvatskoj i Slavoniji s obzirom na državljanstvo i hrvatsko-slavonsku pripadnost u vremenu do sklapanja Hrvatsko-ugarske nagodbe 1868. Nakon toga se analiziraju odredbe Hrvatsko-ugarske nagodbe značajne za zapošljavanje u javnoj upravi u Hrvatskoj i Slavoniji te se izlažu stajališta hrvatske pravne doktrine nagodbenog razdoblja o zapošljavanju u javnoj upravi u Hrvatskoj i Slavoniji. Slijedi analiza zapošljavanja u autonomnoj zemaljskoj upravi, u zdravstvu i školstvu te u zajedničkoj ugarsko-hrvatskoj javnoj upravi. U sklopu tog dijela rada analiziraju se najznačajniji propisi te natječaji objavljivani u Narodnim novinama. Konačno, u zadnjem dijelu rada analizira se veza između namještenja u javnoj upravi i stjecanja ugarsko-hrvatskog državljanstva i hrvatsko-slavonske zavičajnosti.

\section{Zapošljavanje u javnoj upravi u Hrvatskoj i Slavoniji s obzirom na državljanstvo i hrvatsko-slavonsku pripadnost do 1868.}

Značaj problematike zapošljavanja u Hrvatskoj i Slavoniji s obzirom na državljanstvo i hrvatsko-slavonsku pripadnost usko je povezan s nastankom moderne uprave. Tako je materija zapošljavanja domaćił sinova u Hrvatskoj i Slavoniji dobila na važnosti upravo za vrijeme vladavine Marije Terezije kad su se u Hrvatskoj i Slavoniji provodile značajne upravne reforme. Konkretan povod za aktualizaciju problematike zapošljavanja u javnoj upravi bila je kraljičina odluka o osnivanju Hrvatskog kraljevskog vijeća iz 1767. U odluci o osnivanju Kraljevskog vijeća kraljica Marija Terezija je, naime, tek odredila da će prilikom imenovanja uzeti u obzir domaće sinove. ${ }^{1}$ Hrvatski staleži negativno su reagirali na osnivanje Kraljevskog vijeća. Ipak, bude li Vijeće osnovano, Hrvatsko-slavonski sabor je zahtijevao da kraljica u vijeće imenuje samo

1 Odluku o osnivanju Kraljevskog vijeća u kraljevinama Dalmaciji, Hrvatskoj i Slavoniji iz 1767., v. u: Šulek, 1868, str. 202-206. 
domaće sinove te je zahtijevao da ban kao čelnik Hrvatskog kraljevskog vijeća bude samo rođeni krune podložnik (Šulek, 1868, str. 208-209).

Problematika zapošljavanja domaćih sinova bila je značajna i za vrijeme vladavine Josipa II. koji je provodio sveobuhvatnije upravne reforme. Josip II. uveo je njemački jezik kao službeni i u Hrvatsku i Slavoniju te je tako znanje njemačkog jezika propisano kao kriterij za namještenje u službu odnosno za ostanak u službi (Horvat, 1906, str. 5-6). Uvođenje njemačkog jezika išlo je usporedo s namještanjem stranih činovnika. Smrću Josipa II. 1790. Leopold II. prekinuo je s apsolutističkim načinom vladavine, sazvani su sabori te je vraćena ustavnost, a strani činovnici vratili su se u Kranjsku i Štajersku (Horvat, 1906, str. 13).

Neuspjeh reformi Josipa II. te povratak ustavnosti rezultirali su aktualizacijom zahtjeva za namještanjem domaćib sinova u službe u javnoj upravi. $\mathrm{Na}$ tom tragu, Kraljevska akademija znanosti u obraćanju Hrvatsko-slavonskom saboru 19. svibnja 1790. zahtijevala je da u službe pod banskom vlašću budu imenovani samo građani naše domovine (Šidak, 1969, str. 59). Slični su zahtjevi bili prisutni u javnom diskursu i tijekom razdoblja ilirskog preporoda te su kulminirali 1848 . $^{2}$ Tako je $\mathrm{u}$ »Zahtijevanjima naroda « u točki 29. istaknut zahtjev o isključivom pravu pripadnika Trojedne Kraljevine na službe u javnoj upravi. ${ }^{3}$

Uvođenje Oktroiranog ustava u Hrvatsku i Slavoniju u rujnu 1849. godine i formalno je označilo prekid revolucije. Novim Ustavom Hrvatskoj i Slavoniji, kao uostalom i ostatku Monarhije, nametnuta su rješenja kojima je proklamirano jedinstvo Monarhije. Na tom tragu, Ustavom je proklamirano jedno austrijsko državljanstvo za čitavu Monarhiju, dok je negiran značaj pojedinih zemaljskih pripadnosti, uključujući i hrvatsko-slavonske pripadnosti kao osnove posebnih političkih prava, pa tako i prava na zapošljavanje u službama u javnoj upravi (čl. 24. i 27. Oktroiranog ustava iz 1849.). ${ }^{4}$ Ipak, i nakon stupanja na snagu Oktroiranog ustava zadržan je hrvatski jezik kao službeni te je taj kriterij i dalje otežavao dolazak većem broju stranaca u Hrvatsku i Slavoniju. Takvo stanje prekinuto je ukidanjem Ustava Silvestarskim patentom od 31. prosinca 1851. Tijekom narednih osam godina za vrijeme otvorenog apsolutizma vladar je promovirao politiku jake centralizacije Monarhije, unifikacije pravnog sustava te

${ }^{2} \mathrm{U}$ godinama uoči revolucionarne 1848. godine županijske skupštine isticale su zahtjeve za osnivanjem hrvatskog odsjeka Ugarske dvorske kancelarije na čijem čelu bi bio rodoljubni Hrvat (Horvat, 1989, str. 82).

3 Tekst »Zahtijevanja naroda«v. u: Čepulo et al., 2010, str. 39-46.

${ }^{4}$ Tekst Oktroiranog ustava iz 1849. godine v. u: Bernatzik, 1911, str. 150-166. 
snažne germanizacije. U Hrvatsku i Slavoniju stoga je u vremenu od 1852. do 1860. namještano činovništvo iz austrijskih nasljednih zemalja. Zapošljavanje takvog činovništva omogućavalo je pravilo o austrijskom državljanstvu kao temeljnoj pretpostavci zapošljavanja u javnoj upravi te pravilo o njemačkom jeziku kao službenom i u Hrvatskoj i Slavoniji.

Bitne promjene u pogledu zapošljavanja stranaca u Hrvatskoj i Slavoniji nastupile su povratkom ustavnosti 1860. Tad su u pravnom poretku $\mathrm{Hr}$ vatske i Slavonije kao značajni za namještenje uvedeni kriteriji hrvatskoslavonske pripadnosti te poznavanja hrvatskog jezika. Bitna posljedica uspostave tih kriterija bilo je zaoštravanje odnosa zemaljskih vlasti prema stranim činovnicima koji su u Hrvatsku i Slavoniju namješteni tijekom neoapsolutizma. Tim se stranim činovnicima davao otkaz ako nisu poznavali hrvatski jezik. Nadalje, službu u Hrvatskoj i Slavoniji više nisu mogli obnašati ni odvjetnici, javni bilježnici, a ni učitelji koji nisu znali hrvatski jezik (Kosnica, 2013, str. 1153-1154).

Sumiramo li problematiku zapošljavanja u javnoj upravi u Hrvatskoj i Slavoniji u vremenu od reformi Marije Terezije pa sve do sklapanja Hrvatskougarske nagodbe 1868., možemo reći da je s jedne strane vidljivo nastojanje Habsburgovaca, primjetno ponajviše za vrijeme reformi Josipa II. i za vrijeme neoapsolutizma, za namještanjem stranih činovnika u Hrvatsku i Slavoniju te za uvođenjem njemačkog jezika kao službenog. Suprotno tome, vidljivo je i nastojanje hrvatske političke elite za uspostavom hrvatsko-slavonske pripadnosti kao kriterija za zapošljavanje u javnoj upravi. Pri tome iskustvo iz 1860. godine pokazuje da je pored hrvatsko-slavonske pripadnosti značajna barijera većem dolasku stranaca bilo znanje hrvatskog jezika.

\section{Hrvatsko-ugarska nagodba i zapošljavanje u javnoj upravi u Hrvatskoj i Slavoniji}

Državnopravni položaj Hrvatske i Slavonije je u razdoblju od 1868. do 1918. godine bio određen Austro-Ugarskom i Hrvatsko-Ugarskom nagodbom (Gross \& Szabo, 1992, str. 213-238). Pri tome je s obzirom na problematiku zapošljavanja u javnoj upravi svakako vrlo značajna bila podjela nadležnosti uspostavljena tim nagodbama, i to na zajedničke poslove za čitavu Monarhiju, zajedničke poslove za zemlje ugarske krune te na autonomne poslove Hrvatske i Slavonije. ${ }^{5} \mathrm{~S}$ obzirom na takvu podjelu, 916-964.

${ }^{5}$ Detaljno o zajedničkim i autonomnim poslovima v. Pliverić, 1908: str. 801-891, 
samo je zapošljavanje u autonomnim poslovima bilo u nadležnosti hrvatsko-slavonskih organa. Naime, prema važećim propisima banu je dana vrlo široka ovlast imenovanja velikog broja činovnika u zemaljskoj upravi, dok je tek najviše činovnike do uključujući VI. činovničkog razreda imenovao kralj. Ovlast imenovanja nižih činovnika u županijama pripadala je velikim županima (Smrekar, 1899, str. 58; Krišković, 1910, str. 85). ${ }^{6}$

Pored uređenja nadležnosti, vrlo značajna odredba za zapošljavanje u zajedničkoj ugarsko-hrvatskoj javnoj upravi bila je odredba Hrvatsko-ugarske nagodbe sadržana u čl. 46. koja glasi: »Kraljevine Dalmacija, Hrvatska i Slavoniji pako na njihovo zahtijevanje osiguravaju se, da će Središnja vlada tako činovnike za hrvatsko-slavonske odsjeke, koji će se kod iste Središnje vlade ustrojiti, kako također i one svoje organe, koji će u opsegu kraljevina ovih uredovati, obzirom na potrebitu strukovnu vještinu, u koliko to samo moguće bude, imenovati između domaćih sinova kraljevina Dalmacije, Hrvatske i Slavonije. « ${ }^{7}$ Ova je odredba nastala kao rezultat napora hrvatske delegacije da osigura zapošljavanje domaćib sinova u odsjecima kod Središnje vlade te u zajedničkim ugarsko-hrvatskim organima na području Hrvatske i Slavonije, dakle u onim institucijama u kojima je zapošljavanje bilo u nadležnosti Središnje vlade i pojedinih ministarstava te vlade. Josip Pliverić ističe da je tijekom pregovora hrvatske i ugarske delegacije i sam Deak priznao Hrvatima pravo na službe u Hrvatskoj i Slavoniji (Pliverić, 1907, str. 35). Analiza ovog članka pokazuje, međutim, da pravo na zapošljavanje domaćih sinova nije uspostavljeno kao apsolutan imperativ. To se naime vidi iz sintagme ukoliko to samo moguće bude čime je pro futuro omogućena relativizacija ove odredbe te naglašavanje njezina tek instruktivnog karaktera.

Konačno, s obzirom na mogućnost zapošljavanja u autonomnim i zajedničkim službama vrlo su značajne odredbe Hrvatsko-ugarske nagodbe sadržane u čl. 56. i 57. Pri tome je u čl. 56. sadržano pravilo o hrvatskom jeziku kao jedinom službenom u Hrvatskoj i Slavoniji, dok je u čl. 57. izrijekom navedeno da je hrvatski jezik jedini službeni i u zajedničkim ugarsko-hrvatskim organima na teritoriju Hrvatske i Slavonije. Tumačimo li čl. 57. Nagodbe zajedno s čl. 46. Nagodbe o zapošljavanju domaćib sinova u zajedničke službe, možemo izvući zaključak da su s obzirom na režim

${ }^{6}$ Usp. čl. 16. Zakonskog članka II. od godine 1869. o ustrojstvu autonomne hrvatsko-slavonsko-dalmatinske zemaljske vlade, Sbornik zakona i naredaba valjanih za kraljevinu Hrvatsku i Slavoniju (dalje: SZ), 1869, komad III.

${ }^{7}$ Zakonski članak o nagodi koju s jedne strane kraljevina Ugarska, sjedinjena s Erdeljem, s druge strane kraljevine Hrvatska i Slavonija sklopiše za izravnanje postojavših između njih državnopravnih pitanjah. V. u: SZ 1868: komad V. 
uspostavljen Hrvatsko-ugarskom nagodbom u zajedničke ugarsko-hrvatske službe u Hrvatskoj i Slavoniji mogli doduše biti namješteni i oni koji nisu mogli biti smatrani za domaće sinove, no u tom slučaju bilo je nužno da znaju hrvatski jezik.

\section{O zapošljavanju u javnoj upravi u Hrvatskoj i Slavoniji u nagodbenom razdoblju: pravna doktrina}

Najznačajniji hrvatski javnopravni teoretičari nagodbenog razdoblja zastupali su stav o pravu hrvatsko-slavonskih pripadnika na službe u Hrvatskoj i Slavoniji. Tako profesor Josip Pliverić, pozivajući se na čl. 46. Hrvatsko-ugarske nagodbe, zastupa stajalište o pravu domaćib sinova, njegovim rječnikom brvatsko-slavonskih držarljana, na javne službe u Hrvatskoj i Slavoniji (Pliverić, 1907, str. 35). Pliverić analizira zastupljenost hrvatskoslavonskih pripadnika u zajedničkim ugarsko-hrvatskim službama i ističe da se čl. 46. Hrvatsko-ugarske nagodbe ne poštuje u praksi. Navodi da je najviše povreda u pogledu zapošljavanja u zajedničkim ugarsko-hrvatskim službama u Hrvatskoj i Slavoniji počinjeno na željeznici te u šumarskoj upravi (Pliverić, 1907, str. 37). Iako brani stajalište hrvatsko-slavonskih pripadnika na službe u Hrvatskoj i Slavoniji, Pliverić ipak dopušta pravnu mogućnost da u službe budu zaposleni i strani državljani, uključujući i ugarske državljane, no to samo iznimno kad postoji potreba za posebnim stručnim znanjem. Međutim, i u tom slučaju, condicio sine qua non kod takvog zapošljavanja treba biti znanje hrvatskog jezika kandidata (Pliverić, 1907, str. 35). Prema Pliveriću, kriterij znanja hrvatskog jezika i hrvatski jezik kao uredovni jezik ključno su jamstvo ostvarenja čl. 46. Hrvatskougarske nagodbe koji govori o zapošljavanju domaćib sinova u zajedničkim ugarsko-hrvatskim službama. Suprotno tome, mađarski uredovni jezik doveo bi do isključivanja domaćih sinova od zajedničkih službi te do prepuštanja tih službi ugarskim pripadnicima kao što je to, prema Pliveriću, slučaj na željeznicama na kojima se čak i protivno Hrvatsko-ugarskoj nagodbi službuje na mađarskom jeziku (Pliverić, 1907, str. 9).

Nadalje, upravnopravni teoretičar Vinko Krišković također je zastupao tezu o pravu hrvatsko-slavonskih pripadnika na službe u Hrvatskoj i Slavoniji. Pri tome ističe da je pravo na zapošljavanje u javnim službama, pored biračkog prava i posebnog personaliteta (lex patriae), bitno pravo hrvatsko-slavonskih državljana koje nemaju ostali pripadnici zemalja ugarske krune (Krišković, 
1909-1910, str. 82-90). Krišković pravo hrvatsko-slavonskih državljana na autonomne službe u Hrvatskoj i Slavoniji izvlači iz smisla čl. 47. Hrvatsko-ugarske nagodbe kojim je definirana autonomija Hrvatske i Slavonije. Prema Kriškoviću, autonomna nadležnost Hrvatske i Slavonije u zakonodavstvu i izvršnoj vlasti ujedno znači i to da autonomnu javnu službu može u našoj kraljevini obnašati jedino hrvatski pripadnik (Krišković, 1909-1910, str. 85-86). Analizirajući pak pravo na zapošljavanje u zajedničkim ugarskohrvatskim službama u Hrvatskoj i Slavoniji, Krišković se poziva na čl. 46. Nagodbe u kojem je riječ o zapošljavanju domaćih sinova u zajedničke ugarsko-hrvatske službe. Pri tome na temelju tog članka Krišković zaključuje da taj članak naređuje imperativno da se u zajedničke javne službe imaju imenovati domaći sinovi naše kraljevine (Krišković, 1909-1910, str. 86).

Konačno, i ustavnopravni teoretičar Ladislav Polić također na temelju čl. 46. Hrvatsko-ugarske nagodbe zaključuje da pravo na službu u javnoj upravi u Hrvatskoj i Slavoniji imaju samo hrvatski pripadnici (Polić, 1912, str. 119). Polić u raspravi o državljanstvu također ističe primjer dvaju natječaja objavljenih u Narodnim novinama, prvi objavljen 2. lipnja 1869. radi popunjavanja časničkih mjesta u domobranstvu te drugi objavljen tijekom 1884. radi popunjavanja vježbeničkih mjesta u domobranskom sudu u kojima je kao pretpostavka za namještenje navedeno hrvatsko-slavonsko državljanstvo kandidata (Polić, 1912, str. 116).

Hrvatska pravna doktrina nagodbenog razdoblja dominanto je zastupala stajalište o postojanju hrvatsko-slavonskog državljanstva te o pravu hrvatsko-slavonskih državljana na službe u javnoj upravi u Hrvatskoj i Slavoniji, uključujući i službe u zajedničkoj hrvatsko-ugarskoj upravi. Takvo stajalište hrvatski su javnopravni teoretičari temeljili ponajviše na čl. 46. Hrvatsko-ugarske nagodbe koji je sadržavao odredbu o zapošljavanju domaćih sinova u zajedničkim ugarsko-hrvatskim službama u Hrvatskoj i Slavoniji te na autonomnoj nadležnosti hrvatsko-slavonskih organa u pitanjima unutrašnje uprave, bogoštovlja, nastave i pravosuđa. Ovdje ipak treba istaknuti i nekoliko prigovora takvim tezama. Prvi prigovor jest taj što i sam čl. 46. Nagodbe ne govori o apsolutnom imperativu zapošljavanja domaćib sinova Hrvatske i Slavonije, nego je taj članak instruktivno formuliran. Drugi bitan prigovor tiče se upotrebe predmoderne sintagme domaćeg sina koju je upitno izjednačavati s modernim pojmom državljanina. Iz hrvatske perspektive gledano, bitan nedostatak Hrvatsko-ugarske nagodbe bio je u tome što je zakonodavstvo o državljanstvu stavljeno u nadležnost zajedničkog Ugarsko-hrvatskog sabora u kojem su Mađari imali većinu. Rezultat toga bilo je donošenje Zakona o državljanstvu iz 1879. godine kojim je državljanstvo definirano kao jedno za sve zemlje ugarske krune te 
nazvano ugarskim (čl. 1.). ${ }^{8}$ Odredba o zajedničkoj nadležnosti u pitanjima državljanstva otežavala je uspostavu kriterija hrvatsko-slavonske pripadnosti kao značajnog za uživanje prava u Hrvatskoj i Slavoniji. ${ }^{9}$

\section{Zapošljavanje u zemaljskoj upravi (1868. - 1918.)}

U Hrvatskoj i Slavoniji početkom nagodbenog razdoblja problematika zapošljavanja u autonomnoj zemaljskoj upravi s obzirom na državljanstvo i hrvatsko-slavonsku pripadnost nije bila uređena. Hrvatski se pravni poredak po tome bitno razlikovao od primjerice austrijskog pravnog poretka u kojem je već početkom nagodbenog razdoblja temeljnim zakonom o pravima državljana u kraljevinama i zemljama zastupanim u Carevinskom vijeću propisano načelo jednake dostupnosti službi u javnoj upravi svim državljanima te je također propisano austrijsko državljanstvo kao temeljni kriterij za namještenje u javnoj upravi. ${ }^{10}$

Zakon donesen 1869. kojim je uređena Zemaljska vlada također nije sadržavao pretpostavku hrvatsko-slavonske pripadnosti činovnika kao značajnu za namještenje u službi. ${ }^{11}$ Za razliku od šutnje Zakona o zemaljskoj vladi iz 1869., Zakonom o uređenju županija brvatsko-slavonsko-dalmatinsko državljanstvo izrijekom je navedeno kao pretpostavka za zapošljavanje na činovničkim mjestima u hrvatsko-slavonskim županijama (čl. 33.). ${ }^{12} \mathrm{Taj}$ se Zakon odnosio se na zapošljavanje u županijskom magistratu koji se sastojao od više vrsta činovnika među kojima su bili podžupan, veliki bilježnik, podbilježnici, blagajnik, računovođa, arhivist, ostalo kancelarijsko osoblje, mjernik, liječnici, ranarnici, primalje, veterinari (čl. 31.). Pa ipak,

${ }^{8}$ Zakonski članak L., 1879. zajedničkoga Hrvatsko-ugarskoga sabora o stečenju i gubitku ugarskoga državljanstva (SZ, 1880, komad VII).

${ }^{9}$ V. primjer neuspjele reforme odvjetništva u Hrvatskoj i Slavoniji tijekom 1875. godine. Reforma nije uspjela stoga što je Središnja vlada smatrala da navođenje zavičajnosti u Hrvatskoj i Slavoniji kao pretpostavke za obavljanje odvjetništva implicira postojanje hrvatsko-slavonskog državljanstva, što je protivno Hrvatsko-ugarskoj nagodbi (Gross \& Szabo, 1992, str. 377; Čepulo, 2003, str. 84).

10 Temeljni zakon o pravima državljana v. Bernatzik, 1911, str. 422-427.

11 Usp. Zakonski članak II. iz godine 1869. o ustrojstvu autonomne hrvatsko-slavonsko-dalmatinske zemaljske vlade.

12 Zakonski članak XVII. 1870., sabora kraljevina Hrvatske, Slavonije i Dalmacije, ob ustrojstvu županijah istih kraljevinah (SZ, 1871, komad IV). 
osnovni je nedostatak odredbe o zapošljavanju hrvatsko-slavonsko-dalmatinskih državljana bio u tome što koncept hrvatsko-slavonsko-dalmatinskog državljanstva nije bio uređen posebnim zakonom.

Reformama provođenim za vrijeme banovanja Ivana Mažuranića reformiran je županijski sustav tako da su kao temeljne upravne jedince osnovane podžupanije. Zakon kojim su podžupanije uređene nije sadržavao odredbu o hrvatsko-slavonsko-dalmatinskom državljanstvu kao pretpostavci za zapošljavanje u podžupanijama. ${ }^{13}$ Khuenov zakon o županijama iz 1886. također nije sadržavao pretpostavku posebne pripadnosti Hrvatskoj i Slavoniji kao nužnu za zapošljavanje u zemaljskoj upravi. ${ }^{14}$

Za razliku od propisa kojima je reguliran županijski sustav, u propisima kojima su regulirana pojedina upravna područja možemo naići na pretpostavke državljanstva i jezika kao značajne za zapošljavanje. Tako je primjerice u propisu o uređenju zemaljske građevinske službe kao kriterij za zapošljavanje propisano i znanje hrvatskog odnosno srpskog jezika. ${ }^{15} \mathrm{U}$ naredbi Zemaljske vlade iz 1894. kojom je pak uređena cestarska služba kao temeljne pretpostavke za namještenje na radno mjesto cestara navedeni su pak rođenje u Hrvatskoj i Slavoniji ili ugarsko-hrvatsko državljanstvo. ${ }^{16}$

Analiza natječaja objavljivanih u Narodnim novinama pokazuje da se hrvatsko-slavonska pripadnost nije navodila kao formalna pretpostavka za zapošljavanje u autonomnoj zemaljskoj upravi. Štoviše, u prvim godinama nakon sklapanja Hrvatsko-ugarske nagodbe u natječajima nije se navodilo niti državljanstvo. Tako je primjerice zastupstvo grada Varaždina tijekom 1870. raspisalo natječaj za mjesto podblagajnika u gradu Varaždinu. Zainteresirani podnositelji trebali su dokazati stručnu spremu, uzorno ponašanje, dotadašnje službovanje i potpuno poznavanje hrvatskog jezika (NN 1870/22). Nakon stupanja na snagu Zakona o stjecanju i gubitku ugarskog državljanstva početkom 1880. vidljiva je promjena u smjeru navođenja državljanstva kao pretpostavke za zapošljavanje. Tako je u natječaju za radno mjesto zatvorskog nadstražara u Mitrovici iz 1884. kao nužna pretpostavka za zapošljavanje navedeno znanje hrvatskog jezika te

${ }^{13}$ Usp. Zakon o ustroju političke uprave u kraljevini Hrvatskoj i Slavoniji. (SZ, 1874: komad XXIII)

14 Usp. Zakon od 5. veljače 1886. ob ustroju županija i uređenju uprave u županijah i kotarih. (SZ, 1886: komad III).

15 Usp. čl. 8. Zakona od 28. prosinca 1894. ob uređenju građevne službe u kraljevinama Hrvatskoj i Slavoniji (SZ 1895, komad I).

${ }^{16}$ Naredbu v. Smrekar, 1899, str. 158-159. 
državljansko pravo u području ugarske krune (NN 1884/2). Iako se termin ugarsko-hrvatskog državljanstva odnosno državljanstva u zemljama ugarske krune koristio u pravilu, ipak se još tijekom 1880-ih iznimno moglo dogoditi da u natječaj bude uvršten i pravno pogrešan termin austrougarskog državljanstva. Tako je primjerice u natječaju za radno mjesto jednog zatvorskog nadstražara koji je raspisalo ravnateljstvo kaznionice u Gospiću tijekom 1884. naznačeno da podnositelji molbe moraju dokazati znanje hrvatskog jezika te da su austro-ugarski državljani (NN 1884/2).

Uvrštavanje kriterija hrvatskog jezika kao temeljne pretpostavke za zapošljavanje u zemaljskoj upravi u pojedinim natječajima bilo je pravilo. Međutim, analizom pojedinačnih natječaja moguće je uočiti odstupanja od toga pravila. Odstupanja su, naime, vidljiva u natječajima za radna mjesta u strukama autonomne javne uprave u kojima je nedostajalo kvalificiranog osoblja. Tako je primjerice u natječaju za radno mjesto županijskog veterinara iz 1870. među kriterijima za zaposlenje navedeno znanje hrvatsko-srpskoga jezika odnosno drugoga kojega slavenskog jezika (NN 1870/294). Nadalje, iz natječaja koji je Zemaljska vlada raspisala 1884. godine za radna mjesta civilnih tehničara vidi se da znanje hrvatskog jezika nije nužna pretpostavka, nego tek kriterij pomoću kojeg je moguće ostvariti prednost prilikom zapošljavanja (NN 1884/41).

S obzirom na sve navedeno možemo zaključiti da se pretpostavka hrvatsko-slavonske pripadnosti kandidata našla tek u prvom propisu o županijama iz 1870. U kasnijim propisima kriterij hrvatsko-slavonske pripadnosti nije navođen. $U$ pojedinim specijalnim propisima, pa i u natječajima za radna mjesta od 1880-ih u pravilu su se navodili kriteriji državljanstva zemalja ugarske krune i znanja hrvatskog jezika. Pored toga, na temelju teksta pojedinih natječaja moguće je zaključivati i o vrlo tolerantnom, uključujućem stavu vlasti prilikom propisivanja pretpostavki za zapošljavanje, i to u strukama koje nisu bile klasične administrativne, nego se radilo o strukama u kojima su bila nužna specifična znanja.

\section{Zapošljavanje u zdravstvu u Hrvatskoj i Slavoniji (1868. - 1918.)}

Hrvatsko-ugarskom nagodbom autonomni poslovi određeni su generalnom klauzulom, a ukratko su opisno određeni kao unutrašnja uprava, bogoštovlje i nastava te pravosuđe. U sklopu takve resorne podjele zdravstvo je potpadalo pod unutrašnju upravu (Krešić \& Rakitničan, 2015, str. 279). 
To je pak imalo za posljedicu da je zakonodavno uređenje zdravstva bilo u nadležnosti Hrvatsko-slavonskog sabora i kralja, dok je izvršna upravna vlast, uključujući i imenovanja liječnika, pripadala Zemaljskoj vladi odnosno podređenim upravnim tijelima. Prvi u nizu značajnih propisa nagodbenog razdoblja koji se odnosio na status zdravstvenog osoblja bio je već spomenuti Zakon o ustroju županija iz 1870. Tim je propisom uređen status županijskih liječnika, kotarskih ranarnika i primalja, i to tako da su definirani kao županijski činovnici koji su ujedno prije namještanja trebali biti hrvatsko-slavonsko-dalmatinski državljani (čl. 31. i 33. Zakona o ustroju županija iz 1870.). ${ }^{17}$

Zakonom o zdravstvu iz 1874. zemaljski veterinar, podžupanijski liječnik i podžupanijski veterinar svrstani su u kategoriju zemaljskih činovnika (SZ, 1874, str. 440). ${ }^{18}$ Tim Zakonom međutim nisu propisane detaljne pretpostavke za zapošljavanje koje bi se ticale ugarsko-hrvatskog državljanstva ili hrvatsko-slavonske pripadnosti kandidata.

Prema Zakonu koji je uredio zdravstvo 1894. uređeno je pitanje zapošljavanja liječnika u Hrvatskoj i Slavoniji, i to tako da su za javne liječnike mogle biti imenovane osobe s diplomom liječničke struke, pod pretpostavkom da su diplomirale na nekom ugarskom ili austrijskom sveučilištu odnosno da su ta sveučilišta nostrificirala njihovu diplomu te uz pretpostavku da je osoba vješta govorom i pismom hrvatskom ili srpskom jeziku (čl. 3. . ${ }^{19}$ Posebnom uredbom iz 1897 . Zemaljska vlada dopustila je privremeno imenovanje liječnika koji nisu apsolutno vješti hrvatskom jeziku. Te su osobe mogle podnijeti molbu za zaposlenje u zdravstvu te su u takvoj

17 S obzirom na nedostatak kvalificiranog zdravstvenog osoblja opravdano je postaviti pitanje o realnim mogućnostima provedbe takve odredbe. Iz podataka za 1873. koje je Zemaljska vlada prikupila od županija vidi se da velik broj liječnika i primalja nije rođen u Hrvatskoj i Slavoniji, nego su se doselili iz Ugarske i iz austrijskog dijela Monarhije. Pri tome je iz evidencija o tim osobama vidljivo su liječnici i primalje znali hrvatski jezik. V. izvještaj za Vjekoslava Erleweina, kotarskog liječnika u Ludbregu, koji je rođen u Beču 1809. te je također diplomirao u Beču 1837. godine. V. i podatke za Josipa Havraneka, županijskog kotarskog ranarnika Križevačke županije, rođenog u Ugarskoj u Papu u županiji Veszprem, 1805. V. i očevidnik Viekoslava Verniga, kotarskog ranarnika u Koprivnici, rođenog u Ugarskoj u Velikom Varadinu 1820. (HR Hrvatski državni arhiv, Predsjedništvo Zemaljske vlade za kraljevine Hrvatsku, Slavoniju i Dalmaciju, fond 78, kutija 58, VI 20/1873 742-874, izvještaji i očevidnici priloženi uz dopis podžupana Ožegovića upućen Zemaljskoj vladi 21. travnja 1874.).

18 Zakon od 15. studenoga 1874. o uređenju zdravstva u kraljevini Hrvatskoj i Slavoniji (SZ, 1874: komad XXIII).

19 Zakon od 24. siječnja 1894. o uređenju zdravstvene službe u kraljevinama Hrvatskoj i Slavoniji. (SZ, 1894, komad IV); Tekst zakona s komentarom v. Smrekar, 1899, str. 177-195. 
molbi trebale navesti rok u kojem se obvezuju naučiti hrvatski jezik. Tek po proteku tog roka njihova je služba postajala stalna. ${ }^{20}$ Zakonom o zdravstvu iz 1906. godine određeno je da su kao liječnici u Hrvatskoj i Slavoniji mogli biti imenovani samo oni kandidati koji su diplomirali ili su nostrificirali diplomu na Sveučilištu Franje Josipa I. u Zagrebu ili na kojem ugarskom sveučilištu (čl. 11.), dok pretpostavka državljanstva nije navedena. ${ }^{21}$ Uvidom u natječaje objavljivane u Narodnim novinama vidljivo je uključujuće stajalište vlasti te navođenje relativno blagih pretpostavki za zapošljavanje na radno mjesto liječnika. Tako je primjerice tijekom 1870. u Narodnim novinama objavljen natječaj za tri mjesta kotarskih liječnika u Varaždinskoj županiji. Pri tome je značajno da se u natječaju ne spominje hrvatsko-slavonska pripadnost, zavičajnost niti ugarsko-hrvatsko državljanstvo, nego se kao temeljna pretpostavka navodi znanje hrvatsko-srpskoga kao službovnoga ili drugoga kojega slavenskoga jezika (NN 1870/294). Nadalje, možemo spomenuti i natječaj objavljen početkom 1884. u Narodnim novinama za radno mjesto kućnog liječnika u sklopu županijske bolnice u Bjelovaru. $U$ tom natječaju kao ključno navedeno je da osoba dokaže stručnu spremu te znanje hrvatskog ili njemu sličnog jezika (NN 1884/2).

Slično kao i kod liječnika, početkom nagodbenog razdoblja nedostaje i obrazovanih primalja u Hrvatskoj i Slavoniji (Krešić \& Rakitničan, 2015, str. 278). Ipak, osnivanjem Primaljskog učilišta u Zagrebu 1876. te njegovom djelatnošću stvarno je povećan broj obrazovanih primalja, ujedno hrvatsko-slavonskih pripadnica. Naime, to Učilište u pravilu su pohađale domaće djevojke koje su prilikom upisa imale prednost (Krešić \& Rakitničan, 2015, str. 288). Slično kao i kod liječnika, i ovdje je temeljni kriterij za namještenje u službu bilo znanje hrvatskog jezika, s tom razlikom što je kod primalja s obzirom na postojanje domaćeg kadra taj kriterij mogao biti dosljednije proveden. ${ }^{22}$

Analiza zakonodavnog okvira te natječaja objavljivanih u Narodnim novinama pokazuje otvorenost autonomnih hrvatsko-slavonskih vlasti prema dolasku liječnika i primalja s područja izvan Hrvatske i Slavonije. Uključivo stajalište hrvatsko-slavonskih vlasti vidi se naročito u odnosu prema liječ-

${ }^{20} \mathrm{~V}$. Normativnu rješidbu zemaljske vlade, odjela za unutarnje poslove od 15. ožujka 1897. broj 61495 iz 1896. Objavljeno u: (Smrekar, 1899, str. 191-192).

${ }^{21}$ Zakon od 25. ožujka 1906. o zdravstvu (SZ, 1906, komad VII.).

22 V. natječaj iz 1884. koji je raspisala Pakračka podžupanija za radno mjesto općinske primalje u Daruvaru. Među pretpostavkama za zapošljavanje navedeno je potpuno znanje brvatskog jezika u pismu i govoru (NN 1884/41). 
nicima kod kojih je tolerirano i znanje drugog sličnog slavenskog jezika te im je ostavljana mogućnost da hrvatski jezik nauče tijekom službe. Razlog relativno velikoj otvorenosti i širokom definiranju pretpostavki natječaja za radno mjesto liječnika treba tražiti prije svega u nedostatku domaćih liječnika, pa i nepostojanju medicinskog fakulteta u Hrvatskoj i Slavoniji.

\section{Zapošljavanje u školstvu u Hrvatskoj i Slavoniji (1868. - 1918.)}

Početkom nagodbenog razdoblja natječaje za popunjavanje učiteljskih mjesta u školama raspisivala je Crkva, a natječaji su bili vrlo šturi. ${ }^{23}$ Mažuranićev Zakon o školstvu iz 1874. podržavio je školstvo (Čepulo, 2003, str. 174). Zakonom je također izrijekom određeno da su učitelji javnih škola javni činovnici (čl. 109.). ${ }^{24}$ Pri tome su detaljno uređene i pretpostavke za namještenje, i to tako da su stalno namješteni na radno mjesto učitelja mogli biti samo učitelji koji su završili preparandiju u Austro-Ugarskoj Monarhiji (čl. 110. t. 1.). Stranci, nehrvatsko-slavonski pripadnici, ako su završili preparandiju na kojoj hrvatski jezik nije nastavni, trebali su polagati ispit iz hrvatskog jezika (čl. 110. t. 2.).

Nešto drugačiju sliku daje novi Zakon o školstvu iz 1888. te Zakon od 22. siječnja 1894. kojim je ustrojena Zemaljska ženska stručna škola u Zagrebu. ${ }^{25}$ Zakonom o školstvu iz 1888. propisano je da stalno namješteni na radno mjesto učitelja mogu biti samo ugarsko-hrvatski državljani koji su stekli stručnu kvalifikaciju pred ispitnim povjerenstvom u Austro-Ugarskoj Monarhiji (čl. 117. t. 1.). Pri tome isti zakon propisuje da su učitelji koji su stekli stručnu kvalifikaciju na jeziku koji nije hrvatski ili srpski dužni polagati ispit iz hrvatskog ili srpskog jezika (čl. 111. t. 2.). Zakonom o ustroju zemaljske ženske stručne škole u Zagrebu kao temeljna pretpo-

${ }^{23} \mathrm{Na}$ primjeru dvaju natječaja koje su raspisali jedan kapitularni vikarijat (natječaj br. 1670) te jedan župnik (natječaj br. 1695) vidimo da su oba natječaja u pogledu navođenja potrebnih dokaza vrlo šturi te da se u oba natječaja navodi samo kome su i do kojeg roka molitelji dužni podnijeti molbe te se navodi da uz molbe trebaju biti priloženi i dokazi, iako ne i koji (NN 1870/6).

${ }^{24}$ Zakon od 14. listopada 1874. o ustroju pučkih škola i preparandija za pučko učiteljstvo u kraljevinama Hrvatskoj i Slavoniji (SZ, 1874, komad XX).

25 Zakon od 31. listopada 1888., o uređenju pučke nastave i obrazovanja pučkih učitelja u kraljevinama Hrvatskoj i Slavoniji (SZ, 1888, komad XVII); Zakon od 22. siječnja 1894. o uređenju kr. zemaljske ženske stručne škole u Zagrebu (SZ. 1894, komad III). 
stavka za namještenje u učiteljskoj službi također je navedeno ugarskohrvatsko državljanstvo kandidata (čl. 14. t. 1.). Također je određeno da učiteljice koje poučavaju teorijske predmete moraju imati odgovarajuću svjedodžbu stečenu pred ispitnim povjerenstvom u Hrvatskoj i Slavoniji, Ugarskoj odnosno Austriji (čl. 14. t. 3.). Nadalje, zakonom je predviđena mogućnost da se na natječaje za radno mjesto jave i učiteljice koje su stekle kvalifikacije na nastavnom jeziku koji nije hrvatski ili srpski, no u tom su slučaju one trebale položiti ispit iz hrvatskog ili srpskog jezika (čl. 14. t. 4.). Ispit su trebale položiti pred zagrebačkim kraljevskim ispitnim povjerenstvom za učiteljsku službu u višim pučkim školama (čl. 14. t. 4.).

Na prethodnom tragu su i natječaji za radna mjesta objavljivani početkom 20. stoljeća. Iz natječaja proizlazi da su ugarsko-hrvatsko državljanstvo i znanje hrvatskog jezika bile ključne pretpostavke za namještenje u učiteljskoj službi. Tako na primjeru natječaja objavljenog tijekom 1900. za popunjavanje radnog mjesta asistenta na zemaljskom Primaljskom učilištu u Zagrebu vidimo da su kao pretpostavke za zapošljavanje navedeni ugarsko-hrvatsko državljanstvo te vješto znanje hrvatskog jezika u govoru i pismu (NN 1900/43). ${ }^{26}$

S obzirom na sve navedeno možemo zaključiti da Zakon o školstvu iz 1874. ne sadržava kriterije hrvatsko-slavonske pripadnosti i ugarsko-hrvatskog državljanstva kao značajne za ulazak u službu, nego kao ključan sadržava kriterij znanja hrvatskog jezika. Postupno je od 1880-ih kao ključni kriteriji za zapošljavanje u školstvu uvedeno ugarsko-hrvatsko državljanstvo, dok je zadržan kriterij znanja hrvatskog jezika kao odlučan. Pri tome je upravo znanje hrvatskog jezika bilo ključan kriterij primjenom kojeg je velikom broju nastavnika iz Ugarske otežano zapošljavanje u učiteljskoj službi u Hrvatskoj i Slavoniji (Jadi i nevolje hrvatskoga autonomnoga činovništva, 1914, str. 41-42).

\section{Zapošljavanje u zajedničkoj Hrvatsko - ugarskoj upravi (1868. - 1918.)}

Analiza relevantnih propisa nagodbenog razdoblja o zapošljavanju u zajedničkim službama u Hrvatskoj i Slavoniji pokazuje da kriterij domaćeg sina, sadržan u čl. 46. Hrvatsko-ugarske nagodbe o zapošljavanju u za-

26 Natječaj sličnog sadržaja objavljen je i tijekom 1917. godine (NN, 1917, br. 35). 
jedničkoj hrvatsko-ugarskoj javnoj upravi, nije proveden u zajedničkom ugarsko-hrvatskom zakonodavstvu. Tako primjerice Zakon o osposobljenju javnih činovnika iz 1883. kao vrlo značajan propis kojim je uređeno zapošljavanje u zajedničkoj ugarsko-hrvatskoj upravi ne predviđa poseban režim zapošljavanja u Hrvatskoj i Slavoniji s obzirom na državljanstvo odnosno zemaljsku pripadnost. ${ }^{27}$ Tim je Zakonom propisan jedinstven režim za zapošljavanje u svim zemljama ugarske krune te je sukladno tome kao temeljni kriterij za namještenje na stalno radno mjesto državnog činovnika navedeno ugarsko državljanstvo (čl. 1.).

Analiza pojedinih natječaja za radna mjesta u zajedničkim ugarsko-hrvatskim službama pokazuje da se od 1880-ih ugarsko državljanstvo redovito navodilo kao temeljni kriterij za zapošljavanje. ${ }^{28}$ Pored ugarskog državljanstva, konstanta razdoblja je i navođenje kriterija znanja hrvatskog jezika kao temeljnog za zapošljavanje u zajedničkim službama u Hrvatskoj i Slavoniji. Tako se primjerice od kandidata za radno mjesto službenika u ravnateljstvu pošte u Zagrebu raspisanom tijekom 1870. godine tražilo potpuno znanje hrvatskog jezika (NN 1870/21). Da je znanje hrvatskog jezika bilo značajan kriterij za zapošljavanje u zajedničkim uredima u Hrvatskoj i Slavoniji, vidimo i iz natječaja koji je raspisalo ravnateljstvo pošte za Hrvatsku i Slavoniju radi popunjavanja radnog mjesta poštanskog pristupnika II. razreda tijekom 1870. (NN 1870/7). Ista pretpostavka navedena je i u natječaju koji je tijekom 1876. raspisalo zemaljsko financijsko ravnateljstvo za radno mjesto carinskog asistenta (NN 1876/48).

Prethodno izložene pretpostavke ugarskog državljanstva i znanja hrvatskog jezika te njihovo značenje za zapošljavanje i napredovanje u zajedničkim ugarsko-hrvatskim službama u Hrvatskoj i Slavoniji treba ipak u određenoj mjeri relativizirati te staviti u širi kontekst. To se posebno odnosi na kriterij znanja hrvatskog jezika kao ključan za napredovanje u službi. Naime, iz prakse pojedinih ministarstava vidi se da su ona u pojedinim naredbama promovirala mađarski jezik kao pretpostavku promaknuća. ${ }^{29}$ Nadalje, i u pojedinim natječajima objavljenim u Narodnim novinama uz

27 Zakonski članak I.: 1883. zajedničkoga hrvatsko-ugarskoga sabora o osposobljenju javnih činovnika (SZ, 1883, komad XII).

${ }^{28} \mathrm{~V}$. natječaj koji je raspisalo financijsko ravnateljstvo u Vukovaru za radno mjesto financijskog upravnog službenika desetog razreda (NN 1900/2).

${ }^{29}$ V. interpelaciju Milana Amruša s obzirom na naredbu ministra komunikacija Baroša o naukovnom tečaju za zajedničke poštarske i brzojavne činovnike u kojem je naukovni jezik trebao biti mađarski. Polaganje tečaja bilo je uvjet promaknuća. Ispit se polagao na mađarskom jeziku (Stenografski zapisnici, 1889: str. 387-389). 
hrvatski jezik kao kriterij za zapošljavanje izrijekom je naveden mađarski jezik poznavanje kojeg je kandidatu davalo prednost pred kandidatima koji taj jezik nisu znali. Tako je u natječaju za radno mjesto mjerničkog pristava u sklopu ugarskog građevnog ureda u Hrvatskoj i Slavoniji, koji je raspisao ugarski ministar trgovine, izrijekom navedeno da će kandidati koji mogu pored hrvatskog dokazati i znanje mađarskog jezika imati prednost pri zapošljavanju (NN 1900/136).

Bitan pokazatelj nepostojanja formalnih barijera za zapošljavanje ugarskih zavičajnika u zajedničkim ugarsko-hrvatskim službama u Hrvatskoj i Slavoniji vidljiv je i s obzirom na činjenicu da su natječaji za radna mjesta osim u Narodnim novinama redovito objavljivani i na mađarskom jeziku u Pénzügy Közlöny, listu u kojem su objavljivane novosti iz svijeta financija, te ponekad i u Budapesti Közlöny. ${ }^{30}$ Sve navedeno u konačnici je dovelo do zapošljavanja ugarsko - hrvatskih državljana sa zavičajnošću u Ugarskoj od kojih neki nisu znali hrvatski jezik. ${ }^{31}$

U sklopu analize zapošljavanja u zajedničkim ugarsko-hrvatskim službama kao posebnu kategoriju treba navesti i činovnike i namještenike na državnim željeznicama. Ovdje je bilo ključno da je Središnja vlada smatrala državne željeznice poduzećem Ugarske na koje se ne odnose odredbe Nagodbe o jeziku. Zbog navedenog, na željeznicama su u velikom broju zapošljavani ugarsko-hrvatski državljani sa zavičajnošću u Ugarskoj. Tako je primjerice 1903. godine na željeznicama u Zagrebu bilo zaposleno 76\% ugarskih zavičajnika, a samo $24 \%$ hrvatskih zavičajnika. Ugarski zavičajnici činili su natpolovičnu većinu i u Srijemskoj, Zagrebačkoj te Požeškoj županiji dok je podjednak broj hrvatskih i ugarskih zavičajnika bio zaposlen tek u Varaždinskoj županiji. Hrvatski zavičajnici bili su u većini tek u Modruško-riječkoj županiji te u Bjelovarsko-križevačkoj županiji. Podaci o znanju jezika govore u prilog tezi da velik broj željezničkih činovnika nije znao hrvatski jezik. Tako su prema udjelu hrvatskih govornika prednjačile Varaždinska (82\%), Modruško-riječka (77\%), Bjelovarsko-križevačka (75\%) i Zagrebačka (74\%) županija, dok je najlošije stanje s obzirom na

${ }^{30}$ V. natječaj br. 1223 - prs. - 1899 objavljen u: (NN 1900/2), v. i natječaj za radno mjesto stražara koji je raspisalo financijsko ravnateljstvo u Varaždinu tijekom 1900. godine, a koji je objavljen osim u Narodnim Novinama i u »Pénzügy Közlöny«-u te k tome i u »Budapesti Közlöny«-u (NN 1900/86).

${ }^{31} \mathrm{U}$ prilog tome govore i interpelacije pojedinih zastupnika podnošene već tijekom Mažuranićevog banovanja (Šidak et. al., 1968, str. 85). Interpelacije sličnog sadržaja podizane su i za vrijeme Khuenove vladavine. V. interpelaciju križevačkog zastupnika Franje Markovića podnesenu 1888. godine stoga što je u Financijskom ravnateljstvu u Osijeku imenovan činovnik koji nije vješt hrvatskom jeziku (Stenografski zapisnici, 1889, str. 339-340). 
znanje hrvatskog jezika bilo u gradu Zagrebu (29\%), Srijemskoj (45\%) i Požeškoj (58\%) županiji (Dobrovšak, 2008, str. 514).

Konačno, kao vrlo specifično područje zajedničke ugarsko-hrvatske državne uprave treba spomenuti i pomorstvo. $U$ tom su području također vidljiva nastojanja budimpeštanskog centra za zapošljavanjem Mađara te je s druge strane vidljiv i neuspjeh provođenja takve politike. Tako podaci iz 1915. o zapošljavanju na »Adriji«, privilegiranom društvu pod kontrolom ugarske vlade, koje je zapošljavalo i pomorce iz Hrvatskog primorja, govore da su Mađari bili u izrazitoj manjini i to na radnim mjestima kapetana i strojara, dok ih praktički nije bilo među posadom. Ilustrativan je $\mathrm{k}$ tome podatak da se korespondencija s ravnateljstvom u Budimpešti 1902. godine vodila na engleskom jeziku (Barbalić, 1953, str. 107; Bartulović, 2004, str. 33).

S obzirom na sve navedeno možemo zaključiti da je ugarsko-hrvatsko državljanstvo bilo ključna pretpostavka za zapošljavanje u zajedničkih ugarsko-hrvatskim uredima i na željeznicama u Hrvatskoj i Slavoniji. Nadalje, u zajedničkim ugarsko-hrvatskim državnim uredima bitna pretpostavka za zapošljavanje bilo je poznavanje hrvatskog jezika, iako ponekad izigravano. Do obimnijeg zapošljavanja ugarskih zavičajnika došlo je pak na željeznicama, velikim dijelom i zbog neprovođenja odredbe Hrvatsko-ugarske nagodbe o hrvatskom jeziku kao jedinom službenom u Hrvatskoj i Slavoniji. Pri tome podaci o zapošljavanju na željeznicama pokazuju znatno veći udio ugarskih zavičajnika u usporedbi sa zaposlenicima koji nisu znali hrvatski jezik, što upućuje na zaključak da je dio ugarskih zavičajnika znao hrvatski jezik. Pored vrlo značajnih podataka o zapošljavanju na željeznicama, kompleksnost slike dodatno usložnjavaju podaci o relativno malom udjelu Mađara na radnim mjestima u pomorstvu.

\section{Stjecanje državljanstva i zavičajnosti u Hrvatskoj i Slavoniji na temelju službe u javnoj upravi u nagodbenom razdoblju}

Da bismo shvatili svu kompleksnost problematike zapošljavanja u javnoj upravi s obzirom na hrvatsko-slavonsku pripadnost i ugarsko-hrvatsko državljanstvo, nužno je analizirati učinke koje je zapošljavanje u javnoj upravi u Hrvatskoj i Slavoniji imalo na javnopravni status osoba. Pri tome analiza važećih propisa o hrvatskoj zavičajnosti i o ugarsko-hrvatskom državljanstvu pokazuje da se u vremenu od sklapanja Hrvatsko-ugarske 
nagodbe 1868. pa sve do stupanja na snagu Zakona o stjecanju i gubitku ugarskog državljanstva 8. siječnja 1880. ugarsko-hrvatsko državljanstvo u Hrvatskoj i Slavoniji stjecalo temeljem odredbi austrijskog Općeg građanskog zakonika. Prema tom propisu ugarsko-hrvatsko državljanstvo u Hrvatskoj i Slavoniji stjecalo se i namještenjem u stalnu službu u javnoj upravi. Stupanjem na snagu Zakona o stjecanju i gubitku ugarskog drŽavljanstva 8. siječnja 1880. otpala je takva mogućnost jer taj Zakon ne sadržava i zaposlenje u javnoj službi kao osnovu stjecanja državljanstva (Kosnica, 2013, str. 1157-1160).

Analiza važećih propisa o zavičajnosti pokazuje pak da je namještenje u javnoj službi bilo vrlo značajna osnova stjecanja zavičajnosti, kako u razdoblju do stupanja na snagu Zakona o uređenju zavičajnih odnosa 1880. tako i nakon stupanja na snagu tog Zakona. Tako je još Carski patent o općinama iz 1859., koji je početkom nagodbenog razdoblja još uvijek bio na snazi, predvidio namještenje u javnoj službi kao osnovu stjecanja zavičajnosti. Naime, tim je propisom određeno da dvorski i državni činovnici, svećenici i javni učitelji stječu zavičajnost općine u kojoj su stalno namješteni (Mutavdjić, 1894, str. 226). Nadalje, i 1870. donesen Zakon o uređenju općina i trgovišta bez magistrata predviđa stalno namještenje u javnoj upravi kao osnovu stjecanja pripadnosti u općini. Po tom su propisu, kao uostalom i prema propisu iz 1859., zavičajnost stjecali samo stalno namješteni činovnici, dok podvornička služba nije bila valjana osnova za stjecanje zavičajnog prava (Mutavdjić, 1894, str. 211-212). Naposljetku, i Zakon o uređenju zavičajnih odnosa iz 1880. sadržavao je odredbu temeljem koje su zavičajnost u nekoj hrvatsko-slavonskoj općini stjecali i svi stalno namješteni zemaljski činovnici, općinski činovnici, činovnici javnih zaklada, svećenici i učitelji, uz pretpostavku da su ugarsko-hrvatski državljani (čl. 11.).32 Određene dvojbe, pa i nejasnoće u praksi o mogućnosti stjecanja hrvatske zavičajnosti namještenjem u stalnu zajedničku ugarskohrvatsku službu otklonila je Zemaljska vlada tijekom 1880-ih tako da je izrijekom određeno da su zavičajnost u Hrvatskoj i Slavoniji stjecali samo službenici namješteni u službe u autonomnom hrvatsko-slavonskom djelokrugu, dok zapošljavanje u ugarsko-hrvatskim službama u Hrvatskoj i Slavoniji nije rezultiralo promjenom zavičajnosti (Kosnica, 2014, str. 478479). Stjecanje zavičajnosti namještenjem u službu u Hrvatskoj i Slavoniji tako je bilo ovisno o kralju te o autonomnim hrvatsko-slavonskim tijelima

32 Zakon od 30. travnja 1880. o uređenju zavičajnih odnosa u kraljevinama Hrvatskoj i Slavoniji (SZ, 1880, komad IX). 
nadležnim za imenovanja, u pravilu banu te velikom županu (Krišković, 1910, str. 85).

Sažmemo li prethodna izlaganja, možemo konstatirati da je do 1880. na snazi bio režim prema kojem je osoba stalnim namještenjem u činovničkoj službi stjecala ugarsko-hrvatsko državljanstvo te zavičajnost u Hrvatskoj i Slavoniji. Od 1880. ugarsko-hrvatsko državljanstvo više se nije moglo steći namještenjem u službu, dok je i dalje zadržana mogućnost stjecanja hrvatsko-slavonske zavičajnosti namještenjem u službu u sklopu autonomne hrvatsko-slavonske nadležnosti. Na taj su način zavičajnost u nekoj hrvatsko-slavonskoj općini mogli steći svi ugarsko-hrvatski državljani, pa tako i ugarski zavičajnici te zavičajnici grada Rijeke. Suprotno tome, ugarski zavičajnici te zavičajnici grada Rijeke nisu mogli steći hrvatsko-slavonsku zavičajnost namještenjem u zajedničku ugarsko-hrvatsku službu.

\section{Zaključak}

Analiza zapošljavanja u hrvatsko-slavonskoj zemaljskoj upravi i u javnim službama pokazuje da, osim zakona o županijama iz 1870., u hrvatskoslavonskom pravnom poretku nisu uspostavljene formalne barijere koje bi priječile zapošljavanje stranih državljana te ugarskih zavičajnika u autonomnoj javnoj upravi. Nesvrhovitost takvih barijera bila je očita i zbog važećih pravila o stjecanju državljanstva i zavičajnosti prema kojima je do 1880 . namještenjem u stalnu javnu službu osoba stjecala ugarsko-hrvatsko državljanstvo i hrvatsko-slavonsku zavičajnost. Proces formalnog zatvaranja javne uprave za strane državljane možemo pratiti od 1880. kad je otpala mogućnost stjecanja državljanstva namještenjem u službu. Za razliku od uspostave formalnih prepreka u odnosu prema stranim, ponajviše austrijskim državljanima, granice prema ugarskim zavičajnicima ostale su porozne. Naime, s obzirom na činjenicu da hrvatsko-slavonska pripadnost nije uspostavljena kao formalna barijera za zapošljavanje, možemo reći da je ključna prepreka zapošljavanju nehrvatsko-slavonskih pripadnika bila ovlast autonomnih organa da odlučuju o namještenju u službi u javnoj upravi. Uz to, kroz sve nagodbeno razdoblje, bitna zapreka zapošljavanju stranaca bilo je znanje hrvatskog jezika. Pri tome valja naglasiti da se taj kriterij nije dosljedno primjenjivao u strukama u kojima je bio očit nedostatak kvalificiranog osoblja, pa tako primjerice najočitije u zdravstvenoj djelatnosti.

Analiza zapošljavanja u zajedničkim ugarsko-hrvatskim službama do 1880. također pokazuje nepostojanje formalnih barijera koje bi priječile 
zapošljavanje stranih državljana. Tek od stupanja na snagu Zakona o stjecanju i gubitku ugarskog državljanstva 1880. te od propisivanja ugarskog državljanstva kao opće pretpostavke za zapošljavanje u javnoj upravi zakonom iz 1883. možemo govoriti o svojevrsnom »zatvaranju« službi za ugarsko-hrvatske državljane. Analiza pojedinih natječaja za radna mjesta pokazuje da je od tada temeljni kriterij za zapošljavanje u zajedničkoj upravi u Hrvatskoj i Slavoniji bilo ugarsko-hrvatsko državljanstvo. S obzirom na to, možemo reći da odredba Hrvatsko-ugarske nagodbe o zapošljavanju domaćih sinova u zajedničkim službama u Hrvatskoj i Slavoniji nije imala odgovarajuću podršku u propisima, pa ni u pojedinačnim natječajima. U takvim okolnostima, prepreka većem zapošljavanju ugarskih pripadnika bio je kriterij znanja hrvatskog jezika. Pri tome je upravo nepridržavanje pravila o hrvatskom jeziku omogućilo izrazito veliko zapošljavanje ugarskih zavičajnika na željeznicama.

Konačno, možemo zaključiti da hrvatsko-slavonska pripadnost, suprotno »željama« hrvatskih javnopravnih teoretičara s kraja 19. i početka 20. stoljeća, u pravnom poretku Hrvatske i Slavonije nije uspostavljena kao temeljna pretpostavka zapošljavanja u zemaljskoj upravi i zemaljskim javnim službama, a također ni u zajedničkim ugarsko-hrvatskim službama. Činjenica pak da su zaposlenici u autonomnoj javnoj upravi u pravilu bili hrvatski zavičajnici bila je odraz pravila o stjecanju hrvatske zavičajnosti namještenjem u stalnu službu u autonomnoj javnoj upravi. Analizirana građa upućuje na zaključak da je umjesto hrvatsko-slavonske pripadnosti u nizu područja uspostavljen model prema kojem su temeljne pretpostavke za zapošljavanje u javnoj službi bile ugarsko-hrvatsko državljanstvo te znanje hrvatskog jezika. Utoliko je onda znanje jezika, a ne institut hrvatsko-slavonske pripadnosti, bila prepreka većem zapošljavanju ugarskih zavičajnika u Hrvatskoj i Slavoniji. Iznimka od toga bile su državne željeznice.

\section{Literatura}

Barbalić, R. F. (1953). Brodarstvo Rijeke kroz vjekove. U Ravlić, J. (ur.), Rijeka, Hrvatska: Zbornik (str. 93-122). Zagreb, Hrvatska: Matica hrvatska.

Bartulović, Ž. (2004). Sušak 1919.-1947. Državnopravni položaj grada. Rijeka, Hrvatska: Pravni fakultet Sveučilišta u Rijeci, Državni arhiv Rijeka, Adamić.

Bernatzik, E. (hrsg.) (1911). Die österreichischen Verfassungsgesetze: mit Erlaeuterungen [Austrijski ustavni zakon: s objašnjenjima]. Beč, Njemačka. Manzsche k. u. k. Hof- Verlags-und Universitätsbuchhandlung.

Čepulo, D., Krešić, M., Hlavačka, M., \& Reiter, I. (2010). Constitutions of the World from the late 18th Century to the Middle of the 19th Century [Kon- 
stitucije svijeta od kraja 18. stoljeća do sredine 19. stoljeća]. Croatian, Slovenian and Czech Constitutional Documents 1818-1849. [Hrvatski, slovenski i češki ustavni dokumenti 1818-1849.] Vol. 9., Berlin, Njemačka: De Gruyter.

Čepulo, D. (2003). Prava građana i moderne institucije: europska i brvatska pravna tradicija. Zagreb, Hrvatska: Pravni fakultet Sveučilišta u Zagrebu.

Čepulo, D. (1999). Pravo hrvatske zavičajnosti i pitanje hrvatskog i ugarskog državljanstva 1868-1918 - pravni i politički vidovi i poredbena motrišta. Zbornik Pravnog fakulteta u Zagrebu, 49(6), 795-825.

Dobrovšak, Lj. (2008). Zaposlenici na željeznicama u Hrvatskoj 1903. godine. Časopis za suvremenu povijest, 40(2), 489-516.

Gross, M., \& Szabo, A. (1992). Prema brvatskome gradanskom društvu: društveni razvoj u civilnoj Hrvatskoj i Slavoniji šezdesetib i sedamdesetih godina 19. stoljeća. Zagreb, Hrvatska: Globus.

Horvat, J. (1989). Politička povijest Hrvatske, prvi dio. Zagreb, Hrvatska: August Cesarec.

Horvat, R. (1906). Najnovije doba brvatske povijesti. Zagreb, Hrvatska: Matica hrvatska.

Jadi i nevolje hrvatskoga autonomnoga činovništva (1914). Po želji činovništva napisao S-b. L., autonomni činovnik. Preštampano iz Činovničkoga vjesnika. Zagreb, Hrvatska: Tiskara i litografija C. Albrechta.

Kosnica, I. (2013). Državljanstvo i Opći građanski zakonik u Kraljevini Hrvatskoj i Slavoniji od 1853. do 1879. godine. Zbornik Pravnog fakulteta u Zagrebu, 63(56), 1143-1164.

Kosnica, I. (2014). Hrvatsko-slavonska pripadnost u Hrvatskoj i Slavoniji u nagodbenom razdoblju. Hrvatska $i$ komparativna javna uprava - Croatian and Comparative Public Administration, 14(2), 465-492.

Kosnica, I. (2017). Pravni položaj Roma u Hrvatskoj i Slavoniji od 1868. do 1918. Zbornik Pravnog fakulteta Sveučilišta u Rijeci, 38(2), 729-744, https://doi. org/10.30925/zpfsr.38.2.2

Krešić, M., \& Rakitničan, M. (2015). Primaljstvo u Hrvatskoj i Slavoniji 1876.1918.: zakonodavni okvir ustroja primaljske službe. Historijski zbornik, 68(2), 277-295.

Krišković, V. (1909-1910). Upravna nauka i ugarsko-brvatsko upravno pravo. Po predavanjima Prof. Dr. Vinka Kriškovića. Zagreb, Hrvatska: Skripta.

Krišković, V. (1910). Upravno pravo. Predavanja Dr. Vinka Kriškovića, kr. sveuč. profesora na Sveučilištu Franje Josipa I. u Zagrebu. Zagreb, Hrvatska, Skripta.

Mutavdjić, K. (1894). Zavičajno pravo: Zakon od 30. travnja 1880. ob uredjenju zavičajnih odnošaja u kraljevinah Hrvatskoj i Slavoniji i prijašnji propisi o stečenju $i$ gubitku zavičajnoga prava. Zagreb, Hrvatska: Naklada knjižare Lav. Hartmana (Kugli i Deutsch).

Pliverić, J. (1908). Hrvatsko-ugarsko državno pravo. Zagreb, Hrvatska: Društvo hrvatskih sveučilišnih građana za pouku analfabeta.

Pliverić, J. (1907). Spomenica o državnopravnih pitanjï brvatsko-ugarskih. Zagreb, Hrvatska: Kr. zemaljska tiskara. 
Polić, L. (1912). Nacrt Hrvatsko ugarskog državnog prava: popravljeno i dopunjeno izdanje po dru. Poliću. Zagreb, Hrvatska: Skripta.

Smrekar, M. (1899). Priručnik za političku upravnu službu u kraljevinab Hrvatskoj i Slavoniji, knjiga I. Zagreb, Hrvatska: Tiskom i nakladom Ignjata Granitza.

Šidak, J., Gross, M., Karaman, I., \& Šepić, D. (1968). Povijest brvatskog naroda godine 1860-1914. Zagreb, Hrvatska: Školska knjiga.

Šidak, J. (1969). Regia scientiarum academia. U: Šidak, J. (ur.) Spomenica u povodu proslave 300-godišnjice Sveučilišta u Zagrebu, svezak I. (str. 49-78). Zagreb, Hrvatska: Sveučilište u Zagrebu.

Šulek, B. (1868). Naše pravice: Izbor zakona, poveljab i spisab, znamenitib za državno pravo kraljevine dalmatinsko-brvatsko-slavonske od g. 1202-1868. Zagreb, Hrvatska: Tiskom Dragutina Albrechta.

\section{Pravni izvori}

Narodne novine. Zagreb, Hrvatska, 10. siječnja 1870., br. 6.

Narodne novine. Zagreb, Hrvatska, 11. siječnja 1870., br. 7.

Narodne novine. Zagreb, Hrvatska, 27. siječnja 1870., br. 21.

Narodne novine. Zagreb, Hrvatska, 28. siječnja 1870., br. 22.

Narodne novine. Zagreb, Hrvatska, 27. prosinca 1870., br. 294.

Narodne novine. Zagreb, Hrvatska, 29. veljače 1876., br. 48.

Narodne novine. Zagreb, Hrvatska, 3. siječnja 1884., br. 2.

Narodne novine. Zagreb, Hrvatska, 19. veljače 1884., br. 41.

Narodne novine, Zagreb, Hrvatska, 3. siječnja 1900., br. 2.

Narodne novine. Zagreb, Hrvatska, 22. veljače 1900., br. 43.

Narodne Novine. Zagreb, Hrvatska, 13. travnja 1900., br. 86.

Narodne novine. Zagreb, Hrvatska, 15. lipnja 1900., br. 136.

Narodne novine. Zagreb, Hrvatska, 13. veljače 1917., br. 35.

Hrvatski državni arhiv, Predsjedništvo Zemaljske vlade za kraljevine Hrvatsku, Slavoniju i Dalmaciju, fond 78.

Stenografski zapisnici sabora kraljevine Hrvatske, Slavonije i Dalmacije, petogodište 1887-1892. od XXV. do uključivo LXVI. saborske sjednice od 14. svibnja do 5. prosinca 1888., Zagreb, 1889., godina 1888., svezak II.

Zakonski članak o nagodi koju s jedne strane kraljevina Ugarska, sjedinjena s Erdeljem, s druge strane kraljevine Hrvatska i Slavonija sklopiše za izravnanje postojavših između njih državnopravnih pitanjah, Sbornik zakonah i naredabah valjanih za kraljevinu Hrvatsku i Slavoniju, 1868., komad V.

Zakonski članak II: 1869. sabora kraljevine Hrvatske, Slavonije i Dalmacije o ustrojstvu autonomne hrvatsko-slavonsko-dalmatinske zemaljske vlade, Sbornik zakona i naredaba valjanih za kraljevinu Hrvatsku i Slavoniju, 1869., komad III. 
Zakonski članak XVII. 1870., sabora kraljevinah Hrvatske, Slavonije i Dalmacije, ob ustrojstvu županijah istih kraljevinah, Sbornik zakonah i naredabah valjanih za kraljevinu Hrvatsku i Slavoniju, 1870., komad IV.

Zakon od 14. listopada 1874. o ustroju pučkih škola i preparandija za pučko učiteljstvo u kraljevinama Hrvatskoj i Slavoniji, Sbornik zakonah i naredabah valjanih za kraljevinu Hrvatsku i Slavoniju, 1874., komad XX.

Zakon o ustroju političke uprave u kraljevini Hrvatskoj i Slavoniji, Sbornik zakonah i naredabah valjanih za kraljevinu Hrvatsku i Slavoniju, 1874., komad XXIII.

Zakon od 15. studenoga 1874. o uređenju zdravstva u kraljevini Hrvatskoj i Slavoniji, Sbornik zakonah i naredabah valjanih za kraljevinu Hrvatsku i Slavoniju, 1874., komad XXIII.

Zakonski članak L.: 1879. zajedničkoga hrvatsko-ugarskoga sabora o stečenju i gubitku ugarskoga državljanstva, Sbornik zakonah i naredabah valjanih za kraljevinu Hrvatsku i Slavoniju, 1880., komad VII.

Zakon od 30. travnja 1880. o uređenju zavičajnih odnosa u kraljevinama Hrvatskoj i Slavoniji, Sbornik zakona i naredaba valjanih za kraljevine Hrvatsku i Slavoniju, 1880., komad IX.

Zakonski članak I.: 1883. zajedničkoga hrvatsko-ugarskoga sabora o osposobljenju javnih činovnika, Sbornik zakonah i naredabah valjanih za kraljevinu Hrvatsku i Slavoniju, 1883., komad XII.

Zakon od 31. listopada 1888., o uređenju pučke nastave i obrazovanja pučkih učitelja u kraljevinama Hrvatskoj i Slavoniji, Sbornik zakonah i naredabah valjanih za kraljevine Hrvatsku i Slavoniju, 1888., komad XVII.

Zakon od 22. siječnja 1894. o uređenju kr. zemaljske ženske stručne škole u Zagrebu, Sbornik zakonah i naredabah valjanih za kraljevine Hrvatsku i Slavoniju, 1894., komad III.

Zakon od 24. siječnja 1894. godine o uređenju zdravstvene službe u kraljevinama Hrvatskoj i Slavoniji, Sbornik zakona i naredaba valjanib za kraljevine Hrvatsku i Slavoniju, komad IV., 1894.

Zakon od 28. prosinca 1894. o uređenju građevne službe u kraljevinama Hrvatskoj i Slavoniji, Sbornik zakonah i naredabah valjanih za kraljevinu Hrvatsku i Slavoniju, 1895., komad I.

Zakon od 25. ožujka 1906. o zdravstvu, Sbornik zakona i naredaba valjanih za kraljevine Hrvatsku i Slavoniju, 1906., komad VII. 


\title{
PUBLIC ADMINISTRATION RECRUITMENT PRACTICES IN \\ CROATIA AND SLAVONIA (1868-1918) WITH REGARD TO CITIZENSHIP AND CROATIAN-SLAVONIAN AFFILIATION
}

\begin{abstract}
Summary
The paper deals with the concepts of Hungarian-Croatian citizenship and Croatian-Slavonian affiliation and their relevance for biring practices for positions of public office in Croatia-Slavonia in the period from the Croatian-Hungarian Compromise in 1868 until the dissolution of the Austro-Hungarian Monarchy in 1918. The author takes issue with the claim advocated by Croatian public law theoreticians at the end of 19 th and the beginning of the 20th century that Croatian-Slavonian affiliation was a key requirement for positions of public office in Croatia-Slavonia. In support of bis argument the author analyses the relevance of citizenship and Croatian-Slavonian affiliation for biring practices in Croatia-Slavonia in the time before the Croatian-Hungarian Compromise. Further, the author analyses the norms which the Croatian-Hungarian Compromise considered relevant for appointment to public office in Croatia-Slavonia, as well as the stand Croatian legal doctrine bas taken regarding the relevance of Croatian-Slavonian affiliation for employment in public office in Croatia-Slavonia. He goes on to analyse the relevance of Hungarian-Croatian citizenship and Croatian-Slavonian affiliation regarding employment in specific administrative areas, namely autonomous administration, bealthcare, schools and joint Hungarian-Croatian offices in Croatia-Slavonia. The author ends by analysing the relevance of appointment to public office for the acquisition of Hungarian-Croatian citizenship and Croatian-Slavonian affiliation. It is concluded that in the Croatian-Slavonian legal system many administrative areas did not view Croatian-Slavonian affiliation as a key requirement for positions of public office. Instead, the key criteria for employment were Hungarian-Croatian citizenship and a command of the Croatian language. The author states that it was not Croatian-Slavonian affiliation but a command of Croatian that proved to be a key barrier which prevented many Hungarians from being appointed to public office in Croatia-Slavonia. An exception to this were the biring practices of the state railway company, where Hungarian was regularly used even in Croatia-Slavonia.

Keywords: public administration, Croatia and Slavonia, employment, citizenship, Croatian-Slavonian affiliation, Croatian language

